\title{
A Short History of the Right To Petition Government for the Redress of Grievances
}

\author{
Stephen A. Higginson
}

\author{
"Never Was a Right So Much Mystified and Magnified" \\ -John C. Galhoun (Senate, 1840)
}

In colonial America, the right of citizens to petition their assemblies was an affirmative, remedial right which required governmental hearing and response. Because each petition commanded legislative consideration, citizens, in large part, controlled legislative agendas. This original theory and practice of petitioning foundered when abolitionists flooded Congress with petitions during the debates over slavery. As a result, the right of petition was collapsed into the right of free speech and expression-a definitional narrowing which persists to this day.

\section{INTRODUCTION}

The original design of the First Amendment petition clause ${ }^{1}$-stemming from the right to petition local assemblies in colonial America, and

1. "Congress shall make no law .... abridging .... the right of the people . . . to petition the Government for a redress of grievances." U.S. CONST. Amend. I. Because little discussion accompanied the adoption of the petition clause, the Framers' intent is unclear. See infra text accompanying notes 92-99. Blackstone and Story pass over the clause with brief comment, though Story's remark deserves citation:

[The right of petition] would seem unnecessary to be expressly provided for in a republican government, since... [i]t is impossible that it could be practically denied until the spirit of liberty had wholly disappeared, and the people had become so servile and debased as to be unfit to exercise any of the privileges of freemen.

2 Story, Commentaries on the Constirution of the United States 645 (5th ed. 1891) (footnote omitted); see also 1 W. Blackstone, Commentaries 143 (rev. ed. 1978) (petitioning to King); 4 id. at 147 (tumultous petitioning); $c f$. C. Black, Structure and Relationship IN ConSTITUTIONAL LAW 40 (1969) ("the petitioning of a legislative body would seem to be an inherent part of its relation with its constituency").

Little has been written on the history and politics of petitioning. Three broad historical surveys are: D. Smith, The Right to Petition for Redress of Grievances: Constitutional DevelopMENT AND INTERPRETATIONS (1971) (unpublished dissertation); Leys, Petitioning in the Nineteenth and Twentieth Centuries, 3 PoL. STud. 45-64 (1955); Nicholls, Surrogate for Democracy: Nineteenth Century British Petitioning, MD. Historian 43-52 (1974).

Two English pamphleteers addressed Parliament on the right of petition. See Letter from an English Subject to Parliament, The Right of British Subjects, To Petition and Apply to their Representatives, Asserted and Vindicated (1733) (available in Library of Congress); Letter from John Somers to 
forgotten today ${ }^{2}$-included a governmental duty to consider petitioners' grievances. Transported to the national level, however, responsiveness to individual petitions proved problematic. In its early years, Congress attempted to pass favorably or unfavorably on every petition, ${ }^{3}$ but procedural strains soon emerged. Although sheer volume of business eventually might have severed the duty of assembly consideration from First Amendment petitioning, ${ }^{4}$ this result was guaranteed when petitioning became enmeshed in the slavery controversy.

Antebellum Congresses were hostile to abolitionists' prayers and refused to respect petitioners' right to legislative hearing. Members insisted that Congress' competence jurisdictionally did not, and administratively could not, extend to petitions for emancipation. ${ }^{5}$ Instead they adopted a

Parliament, Jura Populi Anglicani: or The Subject's Right of Petitioning Set Forth. Occasioned by the Case of the Kentish Petitioners (London 1701) (available in Library of Congress); $c f$. English Satirist's Anonymous Petition, The Petition of the Sharks of Africa to the British Parliament (circa 1790) ("prey[ing]" that "the Lords Spiritual and Temporal of Great Britain" protect the slave trade, which supplied petitioners with their "moft favorite food-human flefh") (available in Library of Congress).

2. The short line of Supreme Court cases that raise the petition clause, culminating in McDonald v. Smith, 105 S. Ct. 2787, 2793 (1985) (petition right subsumed in guarantee of free expression) (Brennan, J., concurring), consistently err in their interpretation of the petition clause as merely a free expression guarantee. See generally Annotation, The Supreme Court and the First Amendment Right To Petition the Government for a Redress of Grievances, 30 L. Ed. 2d 914-25 (survey of case law). These cases reveal an unstudied treatment of colonial legal history by ignoring the original meaning of the right, and especially its remedial, legislative character. But see Adderley v. Florida, 385 U.S. 39, 49 n.2 (1966) (Douglas, J., dissenting) (tracing history of right to petition).

The complete rejection of the colonial understanding of petitioning is best seen in a recent case expressly denying that any duty of consideration arises from the petition clause. In late 1976, Truman Chase of San Diego, California petitioned Senators Kennedy, Stevenson, and Cranston for assistance with a Social Security claim. Receiving no reply, Chase brought suit protesting abridgment of his First Amendment right to petition. The district court held that:

The plaintiff has confused his right to petition with a supposed right to have his petition

granted or acted upon in a certain way. But no such right is found in the Constitution. . . .

What a Senator does with petitions is absolutely within his discretion and is not a proper

subject of judicial inquiry, even if it might appear that he be grossly abusing that discretion.

Chase v. Kennedy, No. 77-305-T, mem. op. at 2 (S.D. Cal. July 11, 1977), affd, 605 F.2d 561, cert. denied, 444 U.S. 935 (1979); see also Minnesota State Bd. Community Colleges v. Knight, 465 U.S. 217,284 (1984) ("To recognize a constitutional right to participate directly in government policymaking would work a revolution in existing government practices.").

3. 4 A. Hinds, Precedents of the House of Representatives of the United States § 3361 (1907).

4. One point of controversy over the Bill of Rights was the Federalist caution against unalterable "liberties" like jury trial or petitioning, with their insistence that future developments could well make change or even abandonment of such processes desirable. "For God's sake, Gentlemen," one Federalist retorted to early cries for a Bill of Rights, "do not shut the door against improvement." America, N.Y. Daily Advertiser, Dec. 31, 1787, reprinted in 15 The DocumenTARY HiSTORY OF THE RATTfication of THE Constitution 197 (J. Kaminski \& G. Saladino eds. 1984).

5. See infra text accompanying notes 130-32. The Confederate States' Provisional Constitution made this interpretation unequivocal with a deft addendum to the First Amendment: "[Congress shall make no law abridging the right of the people] to petition the Government for a redress of such petitions as the delegated powers of this Government may warrant it to consider and redress." Provisional. Constitution for THE Confederate STATES OF AMERICA art. I, $\$ 7$, cl. 9, reprinted in Statutes at Large of the Provisional Government of the Confederate States of AMERICA (J. Matthews ed. 1864) (emphasis added). 
series of anti-slavery "gag rules" that effectively abolished the right of petition.

\section{Petitioning in Colonial America}

The first recorded act of business in the colony of Connecticut concerned a grievance that one Henry Stiles had "traded a peece [firearm] with the Indians for Corne." The magistrates who formed the colony's first assembly admonished Stiles, and ordered him to regain the instrument ("in a faire \& legall waye"); then, turning to public legislation, the body resolved that "henceforth none $y^{t}$ are within the Jurisdic[tion] of this Court, shall trade with the natiues or Indians any peece or pistoll or gunn or powder or shott...."7

From one colonist's remonstrance against his neighbor, Connecticut's first act was passed. Similarly, other colonial governments, facing the myriad difficulties of settlement and struggling to regulate all dimensions of colonial life, were led "willy-nilly" by their inhabitants' petitions for legislation. ${ }^{8}$ Vested with a variety of police, legislative, and judicial powers, assemblies responded to a wide spectrum of petitioners' concerns. They adjudicated local offenses, disciplined servants' misfeasances, enacted sumptuary laws, regulated tobacco packaging, and controlled colonists' wages. No sharp line dividing constituents from representatives existed to separate control of the legislative agenda from colonists' initiatives. Petitions assured a seamlessness of public and private governance. Assemblies would receive petitions, refer them to committees for consideration, and then act upon the committees' recommendations. This process originated more bills in pre-constitutional America than any other source of legislation. ${ }^{9}$

6. 1 Colonial Records of Connecticut: The Public Records of the Colony of ConNECTICUT 2 (1850) (date of assembly: 1650) [hereinafter CoNNECTICUT RECORDS, cited with date of assembly]. For reasons concerning access to material, this Note focuses on Connecticut history to make inferences about other colonies.

7. Id.

8. Bailyn, The Origins of American Politics, in 1 Perspectives in American History 77-78 (1967); see also R. HaRlow, History of Legislative Methods in the Period Before 1825, at 19-20 (Massachusetts petitioners covered range of issues, "they petitioned for anything they wanted, and their warts were both varied and various;" committees which formed to hear petitions were equally varied); id. at 66 (diversity of Massachusetts committees hearing petitions). See generally M. Clarke, Parliamentary Privilege in the American Colonies 209-10 (1943) (assemblies extended authority by responding to petitioners).

9. Perusal of the Connecticut Records highlights this fact. For example, in the Connecticut General Assembly (its early name was the General Court) session of May, 1773, over five-sixths of the resolutions were direct responses to residents' petitions and still the Assembly postponed consideration of a further 250 petitions, including one petition from a slave. At this session, petitioners prompted a naturalization bill, a reversal of a superior court judgment, debt discharges, public fishery regulations, roadmaking resolutions, Indian land delimitations (upon petition by Indians), town tax revisions, and constable replacements. See 14 Connecticut ReCords 94-132, 152-55 (1773); see 
The dialogue of petition and response between inhabitants and colonial assemblies was intimately related to the structure of colonial politics. ${ }^{10}$ From the beginning, the primary responsibility of colonial assemblies was the settlement of private disputes raised by petitions. The young assemblies, struggling for domestic authority, were especially attentive to citizens' grievances and recognized that responsiveness to petitions was a way of extending their jurisdiction. In addition, the local character of colonial politics, where assemblies responded to information from inhabitants, even the disenfranchised, made petitions vital initiatives for governmental actions.

These conditions were the foundation for colonial assemblies' reliance on, and inhabitants' ready recourse to, petitioning. That is, colonial assemblies, accustomed to quasi-judicial lawmaking and anxious to encourage petitions as sources of both jurisdiction and information, generally favored citizens' rights to assembly consideration.

\section{A. The Judicial Role of Colonial Assemblies}

Connecticut Colony's legislature, like other colonial assemblies, performed both legislative and judicial functions. ${ }^{11}$ Petitions for private bills, petitions for public legislation, and petitions appealing courts' decisions relied on this blurring of legislative and adjudicative processes. Aggrieved persons could reformulate causes of action for judicial redress into grievances of abridged liberties in order to secure legislative relief. At the same time, petitioners' broad right to raise any matter for assembly consideration itself impeded the development of separation of powers in colonial governments. ${ }^{12}$

also R. Bailey, Popular Influence upon Public Policy 61 (1979) (most prolific source of Virginia Colony legislation was petitioning).

10. Descriptions of the colonial practice of petitioning may be found in several works on colonial legislative processes. See, e.g., R. Bushman, King and People in Provincial Massachusetts 46-54 (1985) (discussing colonial petitioning to Crown); M. Clarke, supra note 8; R. Harlow, supra note 8, at 14-19, 64-68, 111 (1917) (general discussion); G. WoOD, The Creation of the AMERICAN REPUBLIC 1776-1787, at 162-96 (1969) (colonial attitudes towards representation seen in petitioning).

R. BAILEY, supra note 9 , gives a picture of early petitioning in the colony of Virginia. All social classes were free to present complaints or requests to the House of Burgesses. Prior to 1660, this was done in person; thereafter, local sheriffs posted notice of courthouse reception dates. In 1666, the House of Burgesses established the Committee for Propositions and Grievances, which was reponsible for investigating petitions. The volume of petitions continued to increase into the eighteenth century; between 1750 and 1800 the legislature received on average over 200 petitions per session. Id. at 23-46. Assembly responsiveness and impartiality depended on the homogeneity of the Virginian colonial community, however. Just as the erosion of this condition reduced the general utility of petitioning in Virginia (after 1800, petitions for legislative reapportionment, for internal improvements, and on slavery matters were tangled in East-West sectional controversy), id. at 169-74, anti-slavery petitioning to Congress was also a casualty of sharp regional and party disputes. See infra Section IV.

11. See M. Clarke, supra note 8, at 15-60.

12. Black, Nathaniel Byfield, 1653-1733, in 62 Publications of the Colonial Society of 


\section{Adjudication of Private Disputes: The Connecticut Colony}

Most petitions in the early colonies involved private disputes that the assemblies, acting in a quasi-judicial capacity, would investigate and resolve. Partly because the early colonies lacked strong judicial institutions, the legislatures heard and resolved these conflicts. ${ }^{13}$

In 1770, Connecticut's General Assembly promulgated only fifteen laws on its own initiative, while acting on over 150 causes, in law and equity, brought by petitioners. ${ }^{14} \mathrm{~A}$ representative complaint alleged that one "George Nichols had in an undue manner by artful and oppressive means . . . obtained and gotten from the petitioner a deed of his house and lands ...."15 The assembly, after considering a detailed committee report, declared the deed null and void. ${ }^{16}$

Most early legislation was of similar minute, adjudicatory character. As a result, it proceeded haphazardly, each bill a response to the special circumstances pleaded by petition. Debt actions, ${ }^{17}$ estate distributions, ${ }^{18}$ and divorce proceedings ${ }^{19}$ were frequently brought by petitioners for legislative settlement. Criminal cases appeared as well, most often in the form of prayers for modification of sentence. ${ }^{20}$ Regularly, the reply to a petitioner was legislation reversing a lower court's judgment. ${ }^{21}$

\section{Adjudication and Public Petitions}

Many petitions prompted legislation of general applicability. For example, in 1723, the Connecticut General Assembly affirmed the Connecticut superior courts' appellate jurisdiction over appeals against non-residents

MASSACHuSETtS 57, 79 (1984).

13. Id. at 58-59; see also Surrency, The Courts in the American Colonies, 11 AM. J. LEGAL HIST. 253, 257-61 (1967) (describing "nebulous beginnings" of independent judiciary in colonies); Amar, A Neo-Federalist View of Article III: Separating the Two Tiers of Federal Jurisdiction, 65 B.U.L. REv. 205, 226-28 n.81 ("In some states the lack of judicial independence led to the widespread assumption of judicial functions by the legislature itself.").

14. W. Hamersley, Connecticut-The Origins of Her Courts and Laws, in 18 Pamphlet ColLECTION, No. 2 (available in Yale Law School Library).

15. 13 CONNECTICUT ReCORDS 319-21 (1770).

16. Id.

17. See, e.g., 6 id. 454 (1724); 10 id. 427-29 (1755); 12 id. 313-14 (1764).

18. See, e.g., 3 id. 190 (1685); 6 id. 349 (1722) (assembly approves guardians' petition to divide estate to finance deceased's son's continued education at Yale College); 10 id. 210-11 (1753).

19. See, e.g., 1 id. 275 (1655); 2 id. 292 \& note * (1676). See generally Divorce ProceEdings, 1724-1800, in City and CounTy Documents, MSS 28B, Series III, H, Item 47, Folder M (examples) (available at New Haven Historical Society).

20. See, e.g., 13 CoNnecticut ReCORDS 160-61 (1669) (petitioner Baptist minister given lenient punishment for performing marriage); 3 id. 197-98 \& note * (1686) (bill passed granting petition for sentencing leniency for youths guilty of " "night walking" " and stealing "water milions" ).

21. See, e.g., 10 id. 215-16 (1753) (petitioner succeeds in staying execution of superior court judgment); 12 id. 307-08 (1764) (superior court judgment held manifestly erroneous on petitioner's appeal). 
upon receipt of a petition against a judicial ruling to the contrary. ${ }^{22}$ In 1686 , in direct response to a petitioner's dispute over the conveyance of inheritance titles, the assembly declared that "all lands dissposed by courts in distributions of estates in land to legatees . . . shall belong to the sayd legatees and their heires and assignes forever."23

In addition to initiating legislation, petitioners also asked for the enforcement of existing laws. Thus, in 1685, the Assembly responded to a petitioner's request for a quasi-judicial opinion affirming a law requiring "[l]ands to be tendered to the Town before they be sold to any but to the inhabitants of the same town where they be situate."24

These quasi-judicial responses to petitions regularly involved extensive factual examinations, for which the Assembly delegated considerable powers to committees ${ }^{25}$ or local officials. ${ }^{26}$ The task of verifying the facts alleged in petitions led to authority to compel the attendance of witnesses and petitioners. ${ }^{27}$ The above actions illustrate the uncircumscribed original and appellate jurisdiction the General Assembly exercised in considering petitions. In fact, the Assembly did not divest itself of significant judicial responsibilities until the adoption of the Connecticut Constitution of $1818 .^{28}$

\section{Fair Hearing and Reformation of the Petitioning Process}

The concentration of legislative and judicial authority in one governing body, coupled with the Colony's growth, led to a backlog of petitions. The priority of fair hearing generated ongoing attempts to retain a semblance of adjudicatory due process in the face of an oppressive number of petitions. This priority was especially manifest in the elaborate rules governing petition pleadings. Specifically, the Assembly's notice and counterpetition rules reflected the judicial character of petition consideration.

22. 6 id. 402 (1723).

23. 3 id. 216-17 \& note $+(1686)$.

24. 3 id. 186 \& note $\S(1685)$.

25. Land boundary issues required especially broad legislative investigation. In 1770 , for example, the General Assembly replied to a land division petition by empowering a committee to redraw jurisdictional lines among three towns. $13 \mathrm{id}$. 398-99 (1770). Note, however, the response to the Assembly from a similarly commissioned committee nearly a century earlier: "finding their task too hard for them, they left it not finished." " 2 id. 86 \& note * (1668).

26. The General Assembly would answer some petitions by ordering town selectmen to arbitrate disputes. E.g., 2 id. 84 (1668) (female petitioner's claim referred to town officials).

27. R. HARLOW, supra note 8, at 111; see, e.g., 6 CoNNECTICUT ReCORDS 54 (1718) (act compelling petitioners' appearance before Assembly). And at times whole assemblies took on an investigatory role. One occurrence in Georgia provides a dramatic illustration of assembly response. The House, acting on petitions which alleged inhuman prison treatment, "immediately resolved itself into a Committee of the Whole House upon said Petition,' and went in a body to the jail to look into the matter." R. HARLOW, supra note 8, at 97 (citation omitted).

28. See generally Judicial and Crvil History of Connecticut, ch. 8 (D. Loomis \& J. Calhoun eds. 1895) (detailing General Assembly evolution). 
Summons requirements were strict, ${ }^{29}$ and petitions often were dismissed or postponed when concerned parties had not received notice. ${ }^{30}$ Adverse testimony was important, for the act of petition or remonstrance "call[ed] for due witness to be borne against it . . .."31

In 1744, the Assembly codified much of the adjudicatory process of petitioning. The new regulations required that adverse parties be cited, that summons and copies of the petition be supplied to all concerned persons, ${ }^{32}$ and that "if upon the tryall of the cause it doth appear that either the petitioners or the person or persons cited doe or have given the other any uniust trouble, the party wronged shall be allowed his iust cost and damages as in other cases." 33

Eighteenth century commercial and demographic expansion in the Colony, along with the concomitant explosion of petitions in both law and equity, led to alterations in the method of legislative consideration. The Assembly sought to balance the guarantees of judicial proceedings against the volume of popular petitioning. Adopting a cautious attitude towards petitioning, "being sensible that the publick charge is much increased by a multiplicity of petitions for things of less value than the charge of deciding them, and the publick affairs also thereby further obstructed,"34 the Assembly moved to restrict the numbers by raising fees for presenting petitions and limiting petitioners' access to the assembly according to amounts in controversy. A 1718 order denied consideration to petitions on matters of less than fifteen pounds. ${ }^{35}$

Additional efforts to streamline the consideration process appeared in a 1762 order, requiring the Assembly secretary and petitioners' agents to regulate the daily flow of petitions by assigning each communication a docket number and confirming notification to concerned parties. ${ }^{36}$ Typically, committees were appointed to recommend actions on each petition; ${ }^{37}$

29. See, e.g., 4 Connecticut Records 273-74 (1698) (petition dismissed for improper summons).

30. See, e.g., 2 id. 247-48 \& note * (1674) (town selectmen's petition for permission to move into Hartford County jurisdiction not acted upon until counter-petitions from neighboring towns solicited and received); see also 2 id. $195 \&$ note $\neq(1673$ ) (action on petition postponed until interested parties were notified); 4 id. 29-30 (1690) (same).

31. 3 id. 72 \& note $\neq(1680)$ (petitioner, charged with contempt, given right to appear and defend in Assembly and, editor implies, right to summon accuser).

32. The exchange had to occur five days prior to the assembly hearing. 9 id. 61 (1744).

33. 4 id. 246 (1698).

34. 6 id. 54 (1718). See generally R. HARLow, supra note 8, at 64 ("Probably the greatest defect in procedure in the average colonial assembly had been the want of time-sharing schemes for dealing with petitions.").

35. 6 ConNECTICUT RECORDS 54 (1718) (actual "tryal" cost petitioners the additional sum of three pounds).

36. 12 id. 63 (1762).

37. See 9 id. 60 (1744) (committee's authority to gather evidence included power to compel parties to appear and be examined under oath). 
the assembly could abbreviate this process with direct debate and hand vote resolution. ${ }^{38}$ Still, by late 1769 , the business of adjudicating petitions became so onerous that the Assembly experimented by withdrawing the right of parties to hearings "viva voce" before the Assembly. ${ }^{30}$ These provisions, a first trespass on the adjudicatory process of petition consideration, were hastily repealed as detrimental to the rights of the populace. ${ }^{40}$ Whereas conditions of admissibility, such as amounts in controversy, were manipulated to ease the pressure of petitions, the judicial guarantee of full consideration for those petitions still heard remained inviolate.

The colonial assemblies did retain one important and longstanding restraint on petitioning, again of judicial character: the threat of contempt proceedings. Allegations discovered to be ambiguous or false could lead to dismissal $^{41}$ or to charges against the petitioner. In an early session, a Hartford petitioner was held in contempt for not substantiating his accusatory petition. ${ }^{12}$ Petitioners faced more severe contempt charges when their prayers challenged colonial laws. ${ }^{43}$ Thus, in 1675 , recalcitrant petitioners from Stonington, who desired either the annulment of "prejudiciall" tax laws or "a clear discovery of the rule and reason upon which such acts are grounded,"44 provoked the Assembly's ire. Deciding that "such practices ought to be crushed and due testimonie to be borne against the same," the Assembly punished the petitioners with fines and barred several from public office. ${ }^{45}$

38. $2 \mathrm{id.} 188$ (1672) (direct debate over petition for land grants resulting in fine remission); $2 \mathrm{id.}$ 79 (1667) (petition appealing lower court fine decided by hand vote).

39. 13 id. 301 (1770).

40. 14 id. 79 (1773). Some restrictions were retained. For instance, controversies valued under \& 100 , hitherto brought by petition to the Assembly, were diverted to lower courts. Id.

41. See, e.g., 4 id. 55 (1691) (landowners' petition for township status dismissed because "none of the principle proprietors of sayd land [were] in the petition").

42. 1 id. 111 (1644).

43. See, e.g., 3 id. $72-73$ \& note $\neq(1680)$ (contempt punishment for abusive petition protesting colony laws and governor's actions); see also $1 \mathrm{~W}$. McLoughlin, $1 \mathrm{NEW}$ ENGLAND Dissent, 1630-1833: The Baptists and the Separation of Church and State 71-72 (1971) (Massachusetts General Court interpreting clemency petition as affront to justice, forced some of sixty-six signers to retract statements and fined others). Compare 3 Commons DeBATES, 1621 (W. Notestein, F. Relf \& H. Simpson eds. 1935) (petitioner alleging bribery ordered to appear "and iustyfy his petition or be punished"; subsequently, petition declared "scandalous" for lack of proof, but lenient punishment was advised so as "not to affright men from complaynt nor yet to give too much libertye." 4 Id. 404).

44. 2 Connecticut Records 577 app. (1675) (full text of petition).

45. Id. at 258-59 (1675).

These several colonial episodes of conflict between the right to petition and the integrity of legislative bodies anticipated the nineteenth century controversy in Congress. If communications to one's representative could be arbitrarily ignored, refused, or punished as intrusions on legislative freedom, popular sovereignty was threatened. See G. Wood, supra note 10 , at 363 (For radical Whigs, petitions, instructions, and direct democracy were tied to distrust of representative institutions and refusal to identify individuals' rights with, or subordinate them to, the wills of elected representatives.). Undue assertions of parliamentary privilege-punishing petitioners who were said to menace the dignity of the assembly-jeopardized the entire institution of petitioning. 


\section{B. Petitions and the Extension of Legislative Jurisdiction}

Colonial assemblies seized on petitions to extend their authority. ${ }^{46}$ Struggling for authority to tax and, above all, to legislate, the young assemblies drew on their close associations with local inhabitants to legitimize their activities. ${ }^{47}$ Petitioners often appealed for extraordinary relief, especially when existing law supplied no remedy. The trend of favorable assembly responses shows a steady extension of legislative reach into intercolony militia concerns, ${ }^{48}$ local welfare, ${ }^{48}$ the regulation of private law enforcement $^{\mathrm{s0}}$ and Indian affairs, ${ }^{51}$ all matters previously left either to private responsibility or to British authority.

Assembly aggrandizement was particularly enhanced by the volume of petitions calling for legislative responses in such areas as tax policy, ${ }^{52}$ land distribution, ${ }^{53}$ monopoly grants, and trade and licensing privileges. ${ }^{54}$ Manufacturing and turnpike companies, bank charters, ferry privileges and a variety of other operations in Connecticut's early economy were all acquired through petitions for assembly approval. Assembly authority necessarily expanded in schizophrenic manner. Petitioners retained vital, albeit uncoordinated, lawmaking initiative. Bills responded to the circumstances recited by each petition. Thus, for example, the Colony's tax laws

46. See generally J. Green, The Quest for Power: The Lower Houses of Assembly in THE SOUTHERN ROYAL. ColonIES 1689-1776, at 14-15 (1963) (consolidation of lower houses' power relied on representational link to colonists); M. Kammen, Deputyes and Libertyes: Origins of Representative Government in Colonial America 10 (1969) (aggressive lower houses sought jurisdiction and power to initiate laws).

47. By the end of the seventeenth century, assemblies in all the colonies, save perhaps Delaware, had formed committees to consider grievances. R. HARLow, supra note 8 , at 9 .

48. See, e.g., 2 Connecticut Records 276 (1676) (mother's successful petition for funds for neighboring colony's treatment and release of wounded militiaman).

49. See, e.g., 2 id. 255 (1675) (assembly intervenes to guarantee meadow lands to petitioner); 2 id. 326 (1677) (petition for child custody and support); $12 \mathrm{id.} \mathrm{309-10} \mathrm{(1764)} \mathrm{(petition} \mathrm{for} \mathrm{child} \mathrm{support}$ funds); 13 id. 612 (1772) (ill minister's prayer for family support granted); see also Olson, Agricultural Economy and the Population in Eighteenth-Century Connecticut, in 40 TERCENTENARY CoMMISSION OF THE STATE OF CoNNECTICUT 25 (1935) (Bakhamsted and Colebrook town petitions in 1780 for tax abatement on grounds of impoverishment and infertile lands).

50. See, e.g., 2 ConNECTICUT RECORDs 254 (1675) (Assembly order for estate seizure if court judgment for petitioner ignored); 3 id. 203-04 (1686) (constable sent to caution petitioner's cattlethieving son); 13 id. 613 (1772) (assembly approval of petitioner's request for costs of apprehending felon).

51. See, e.g., 4 id. 280 (1698) (Indians' petition for colony protectorship approved).

52. See, e.g., infra note 56.

53. See, e.g., 2 id. 188 (1672) ( $\mathrm{mix}$ of tax and land policies in response to petition); 2 id. 210 (1673) (petition that land be granted for plantation). See generally Bailyn, supra note 8, at 79 (considerable power of colonial assemblies over land distribution).

54. See, e.g., 1 ConNECTICUT ReCORDS 309 (1657-58) (petition for right to contract with Indians); 2 id. 108 (1669) (tax relief to petitioner owning iron works); 2 id. 254-55 (1675) (ten year monopoly and tax immunity awarded to petitioner constructing mill to produce and export "rape oyle"); 2 id. 325 (1677) (petition for special export license); 4 id. 139 (1695) (petitions for permission to practice medicine); 4 id. 263 (1698) (petitioner authorized to levy bridge toll); $14 \mathrm{id} .128$ (1773) (petition for fishery privileges). 
were a babel of special measures enacted in response to individuals and towns' petitions for particular relief. ${ }^{.5}$

The jurisdictional growth of assemblies through the receipt and disposition of petitions was a complex process, forcing the legislatures to be sensitive to competing interests. Petitions for privileges and dispensations, such as fishery rights, land grants or town boundaries, indeed petitions on most controversial issues, involved a series of communications. A petitioner's application commonly led to an initial notice from the assembly soliciting counter-petitions. A committee examination followed, involving contact with all affected groups. Lastly, the assembly tallied the petitioners' requests, appraised the committee reports, and acted according to the public will. ${ }^{.6}$ Latent in this sequence was petitioners' threat of appeal through petitions to English authority. ${ }^{57}$

Colonial assemblies also used petitions to extend their authority against gubernatorial powers and to support jurisdictional claims against neighboring colonies. For example, in the spring of 1670, Connecticut's Governor Winthrop refused to grant the petition of Narragansett inhabitants who opposed Rhode Island's claims to the region. ${ }^{58}$ Winthrop, who had himself negotiated the territorial concession, spoke against the General Assembly's jurisdictional authority to advocate the petitioners' prayer. His objection was ignored; ${ }^{\text {s9 }}$ in fact, several years earlier the Assembly had responded to proprietors' petitions by repudiating the governor's agreement "inasmuch as it was entered into without authority from the General [Assembly]."

The General Assembly's handling of several other petitions suggests its ability to restrain the authority of governors. Indians who petitioned for

55. See, e.g., 1 id. 201 (1649) (petitions led to tax modifications); 2 id. 188 (1672) (same); 2 id. 309 (1677) (same); 4 id. 55 (1691) (same); 14 id. 120 (1773) (same).

56. Jefferson's "Bill for Religious Freedom" was enacted in this manner. Between 1776 and 1786, several sessions of Virginia's House of Burgesses were "literally flooded" with petitions demanding dissenters' exemptions from taxes to support the Anglican Church. At last in 1785, the assembly formally requested Virginians to express their views. Thousands of petitions came in reply; over 11,000 opposed an assessment bill and just over 1,000 were in favor. R. BAILEY, supra note 9, at 46.

57. A Quaker petition of 1708 read "we are very desireous to have those Laws repealed . . which Indeed seemeth little less than oppression. Otherwise wee think it our duty to address the Queen ...." $1 \mathrm{~W}$. McLoughurn, supra note 43, at 165. For additional examples, see id. at 181 (Quakers send agent to petition Queen Anne against restraints on religious freedom imposed by Massachusetts Colony); id. at 190-97 (Quakers threaten to petition Crown against assessments); id. at 395 (Separates send agent to England to petition); id. at 536-45 (Baptist petition against ministerial support law dismissed; petitioners appeal to England where law disallowed).

58. 2 ConNECTICUT RecoRds 526-41 (1665-77), especially 533-34 (1669-70). "Harmon Garret, alias Wequascooke, Governor of the Pequots" petitioned for protection and described the threatening Rhode Islanders as " "men that weare hats \& cloaths like Englishmen, but have dealt with us like wolves and beares," "id. at 529 (1667).

59. Id. at 534 (1670).

60. Id. at 527 (1663). 
the governor's benefactorship addressed their petition to the Assembly; ${ }^{\mathbf{6 1}}$ the governor's own guard had to petition the Assembly for their arms and expenses; ${ }^{62}$ and when petitions did go before the governor, they frequently came on referral from the Assembly. ${ }^{63}$ When abusive petitions were sent directly to the governor, final authority for contempt proceedings rested in the Assembly's discretion. ${ }^{64}$

Boundary petitions enabled the General Assembly to assert jurisdictional claims against neighboring colonies. Connecticut pressed its dispute with Rhode Island ${ }^{85}$ on the ground that the inhabitants of the disputed lands, through petitions, had indicated that Connecticut was their preferred government. ${ }^{68}$ In its negotiations with Rhode Island, the Connecticut Assembly insisted on its duty to respond to petitioners, to do "what duty requires of us, in order to the relief of $o^{r}$ oppressed neighbours ....?"s87

Still more dramatic was the Connecticut Assembly's use of petitions to repeal a 1713 border agreement with Massachusetts. During negotiation of the agreement, the towns ceded to Massachusetts had not been consulted. Higher Massachusetts taxes provoked these towns, in 1747, to petition for re-joinder with Connecticut. Ignoring its agreement, the General Assembly voted to receive the petitioning towns. ${ }^{68}$

Colonial assemblies similarly employed petitions to test and extend authority against British control. The numerous petitions for land grants facilitated the Connecticut Assembly's hasty distribution of territory to private owners. The action was provoked by the impending arrival of Sir Edmund Andros and the Crown's seizure of the New England colonies' governments and property. ${ }^{60}$ Another incident arose from the fact that petitioners were often awarded trade privileges "any law to the contrary notwithstanding."70 In 1709, when England passed a harsh customs law which Connecticut colonists thought infringed their charter rights, the Assembly took advantage of petitions from shipowners whose vessels had been seized to challenge the authority of the royal collector. Despite his

\footnotetext{
61. 4 id. 280 (1698).

62. 14 id. 122 (1773).

63. See, e.g., 4 id. 215, 217 (1697) (assembly referred petition from town of Wallingford to governor).

64. See, e.g., 3 id. 72 \& note $\dagger(1680)$, supra in note 43.

65. See supra notes 58-60 and accompanying text.

66. 2 Connecticut Records 527 (1663).

67. Id. at $534(1670)$.

68. See Hooker, Boundaries of Connecticut, in 11 Tercentenary Commission of the State of ConNecticut 21 (1933).

69. 3 Connecticut ReCords 220-21 (1686), 225 \& note $\dagger$ (1686-87) (plantation lands distributed to petitioners).

70. 2 id. 325 (1677).
} 
protestations against the exercise of jurisdiction by colonial courts, the collector was evicted from office. ${ }^{71}$

\section{Petitions as Sources of Information in Colonial Politics}

The adjudicatory character of early legislation and the colonial assemblies' self-aggrandizing efforts were predicated on the local nature of colonial politics. In communities that lacked developed media or party structures and that provided limited suffrage, petitioning supplied vital information to assemblies. Few representatives were trained as legislators; most were farmers, holding short terms of office and busy with private responsibilities. They had neither time nor expertise to discover independently the colony's woes or to determine solutions.

Thus, the town of Stonington began a 1668 petition with a common preface:

'Least multitude of busines might overwhelme you, $\&$ and our beeing remoat \& as ovt of sight might too much burie us in oblivion, or want of information might render you the les sensible of our condition, wee make bold to remind you, \& if it maye bee to add a litell breath to the saylls and fethers to the winges of your solicitous indeavours in our behalfe . . . .72

Information from petitions was essential to the Colony's system of providing for those in need. Public funds to reimburse those who cared for orphans, the sick, or the insane, assistance to towns in times of hardship, and protection of debtors all depended upon the continual flow of petitions from individuals and towns. ${ }^{73}$

Not only the enfranchised population, but also unrepresented groups-notably women, ${ }^{74}$ felons, ${ }^{78}$ Indians, ${ }^{78}$ and, in some cases, slaves $^{77}$-represented themselves and voiced grievances through petitions. This broadening of participation and access to relief mitigated some of the hardship of limited colonial suffrage. The right to petition vested these groups with a minimum form of citizenship: petitioning meant that no group in colonial society was entirely without political power.

71. See Hooker, The Colonial Trade of Connecticut, in 50 Tercentenary Commission of the StATE of ConNecticut 18-25 (1936).

72. 2 Connecticut ReCoRdS 530 (1668).

73. See, e.g., supra note 49.

74. See, e.g., 1 CoNnecricur Reconds 319 \& note $\neq(1658)$ (women petitioners complaining of minister's indiscretion and seeking replacement); see also supra note 26 (female petition).

75. See, e.g., supra note 27 (example of prisoner's petition).

76. See, e.g., 3 Connecticur Records 219 (1686) (Podunck Indian land petition); 4 id. 280 (1698) (Pequott Indian petition); 14 id. 130 (1773) (Massatucksett tribe land petition).

77. See, e.g., 2 Public Records of the State of Connecticut, 1778-1780, at 427-28 (1779) (approval of emancipation petition from "a negro man slave" owned by resident who joined British). 
Legislation, particularly concerning agricultural and commercial developments, ${ }^{78}$ proceeded in trial-and-error fashion and was periodically modified according to the opinions of petitioners. Information from petitions also led to foundings of new towns and counties, ${ }^{79}$ settlements of boundary disputes $^{80}$ and efforts at internal improvements. ${ }^{81}$ The history of roadmaking in colonial Connecticut can be traced through colonists' petitions to their towns and the General Assembly. Petitioners seeking convenient routes to Sabbath gatherings, for example, confronted counter-petitioners who were fearful that roads would cut up their tillage. ${ }^{82}$

Petitioning was also used to expose public oppressions. Maladministration or corruption among public agents, ${ }^{83}$ excessive taxation, ${ }^{84}$ injustices perpetrated by courts ${ }^{85}$ and misconduct by local officials (for example, bad magistrates ${ }^{88}$ or lax church wardens ${ }^{87}$ ) were brought to public attention by petitioners' ire.

Glose assembly oversight of colonists' spiritual behavior was assured by the stream of information from ecclesiastical petitions. ${ }^{88}$ This area especially was marked by a dynamic exchange of petitions and counter-petitions. The Massachusetts and Connecticut colonial records are replete with petitions from dissenters who sought to disestablish the Congregational churches. ${ }^{89}$ Religious taxation caused particular controversy. For

78. See, e.g., 3 CONNECTICUT RECORDS 216 (1886) (town petition for crop protection leading to order that proprietors fence land); 7 id. 480-81 (1773)(petitioners' information of cattle thefts prompting criminal enactment); see also supra note 54.

79. See, e.g., 3 id. 240 (1687) (petition leading to founding of town of Danbury).

80. See, e.g., 2 id. 65-66 (1667) (committee to settle boundary disputes established in response to petition); 3 id. 203 (1686) (officers appointed to study boundary dispute between Norwalk and Fairfield in response to petition).

81. See, e.g., 14 id. 96-97 (1773) (petition for lottery privilege to raise funds to dredge Connecticut River); id. at 117 (1773) (fisheries commission formed upon petitioner's motion); id. at 118-19 (petition to develop river landing approved).

82. See, e.g., 2 id. 255 (1675) (petition leading to bill for highway construction); 14 id. 118 (1773) (selectmen petition for replanning of impassable roads); $15 \mathrm{id} .161$ (1775) (petition leading to taxation for highway repair). See generally Mitchell, Roads and Road-Making in Colonial Connecticut, in 14 Tercentenary Commission of the State of Connecticut 6, 8 (1933) (persons' communications to Assembly concerning roads).

83. See, e.g., 14 ConNECTICUT RECORDS 132-33 (1773) (New London petitioners' complaints against indolent constable and tax collector led to new appointment).

84. See, e.g., 1 id. 201 (1649) (petitions by Stratford inhabitants against tax confusion; assembly ordered town leaders to explain rates to townspersons).

85. Sentence modifications were a common response to petitions. E.g., supra note 20.

86. See, e.g., 2 ConNecticut ReCORDs $115 \&$ note $\neq$ (1669).

87. See, e.g., supra note 74 .

88. See, e.g., 1 W. McLoughlin, supra note 43, (New England colonies assemblies' responses to Baptists petitions); 2 ConNeCTICUT ReCORDS 71 \& note (1667) (town petition to form church).

89. Likewise, Baptist towns provoked Congregationalists to petition for relief. In 1711, for example, the Congregationalists of Swansea, Massachusetts petitioned the General Court to divide Swansea into two towns. Conscious of the volatile circumstances surrounding the request, the Court invited Swansea's selectmen to counter-petition. Elaborate legal arguments and accusations were exchanged. The Court considered more petitions and appointed a committee to investigate; the Congregationalists threatened to petition the Privy Council. At last, in 1727, the Congregationalist town of Barrington 
instance, when a tax exemption law expired in 1739, Massachusetts Baptists commissioned agents to petition the General Court [Assembly] for reenactment. The petitioners were requested to submit preferred measures; when the Assembly made revisions, the Baptists' agents drafted a second petition protesting that the changes "by no means redress the Grievances complained of by ye people called Baptists." "’o

\section{The Bill of Rights and the New Nation}

The right of petition, so fundamental in colonial politics, was included in the Bill of Rights. ${ }^{.1}$ That the Framers meant to imply a corresponding governmental duty of a fair hearing seems clear given the history of petitioning in the colonies and the colonists' outrage at England's refusal to listen to their grievances. ${ }^{92}$

The ratification controversy itself was, in large part, a debate among Federalist and Antifederalist petitioners and state assemblies. In Delaware, New Jersey, and Pennsylvania, widespread petitioning provided the catalyst for ratification conventions. ${ }^{93}$

Although Congress, in its first session, approved the right of petition virtually without comment, two historic episodes are noteworthy. First, when Madison introduced his proposed list of amendments on June 8, 1789 , he separated the clause for the rights of assembly, consultation, and petition from the clause containing the free expression guarantees of

was formed. $1 \mathrm{~W}$. McLoughuin, supra note 43 , at 140-46.

90. Quoted in id. 239-41, 239. The Connecticut Assembly also passed a bill granting a religious tax exemption to petitioning Baptists. 7 ConNECTICur Records 257 (1729).

91. See supra note 1; see also 2 The Works of DaNiel. Webster 232-33 (1858) (reception and consideration of petitions were among first actions of House of Representatives in 1789).

92. "In every stage of these Oppressions We have Petitioned for Redress in the most humble terms: Our repeated Petitions have been answered only by repeated injury." The Declaration of Independence para. 30 (U.S. 1776); see also 1 Journals of Congress 67-92 (1775) (petition to King); id. at 117-18 (resolution protesting Parliament's interference with right of petition); 2 JourNaLs of CoNGRess 158-62 (1777) (petition to King).

93. 3 The Documentary History of the Ratification of the Constitution 50-54 (M. Jensen ed. 1978) (Delaware); id. at 134-37 (New Jersey). In Pennsylvania, Federalists circulating petitions harassed and blacklisted citizens who refused to sign. 2 THE Documentary History of the Ratification of the Constitution 620 (M. Jensen ed. 1976). Between September 24 and $29,1787,4,000$ persons petitioned the legislature, $i d$. at 130 , whose resolution calling for a convention expressly rested on "the sense of great numbers of the good people of this state, already signified in petitions and declarations to this House ...."Id. at 101. After ratification, the Antifederalists launched a counter-petition campaign to reverse the results. Id. at 709-24. Eventually, over 6,000 citizens petitioned the assembly. Despite its failure, this well documented counter-petition campaign provides vivid insight into the mechanics of petitioning (e.g., form petitions, distributions, counterpetitions, solicitation strategies) just prior to adoption of the petition clause in the Bill of Rights.

Significantly, the Pennsylvania Assembly's decision "not to attend to" a petition of 750 inhabitants opposed to ratification provoked outcry against such "contempt and obloquy" of petitioners' rights. 15 The Documentary History of the Ratification of the Constitution, supra note 4, at 44. The Philadelphia Independent Gazetteer (Dec. 19, 1787) responded: "Is it improper for freemen to petition for their rights? If it be; then I say that the impropriety consisted only in their not demanding them." Id. at 45 . 
speech and the press. ${ }^{94}$ The express function of the assembly-petition clause was to protect citizens "applying to the Legislature . . . for a redress of their grievances."

Second, both the House and Senate debated whether to include with the guarantees of free speech, press, and petition, "the people's right to 'instruct their Representatives." "'88 Members defeated the amendment ${ }^{97}$ because they feared that obligatory instructions would subvert Congress' deliberative character and lead to irreconcilable factionalism. Yet, in statements denying the right, members expressly affirmed Congress' duty to receive and consider, although not to be bound by, citizens' communications. Thus, while refusing to vest individuals and groups with the power to bind Congress, and while guarding jealously their discretion to judge and reject instructions as unwise, the Framers of the Bill of Rights nonetheless maintained that citizens' "instructions," like petitions, would be heard and considered. ${ }^{98}$

Indeed, in Congress' first decades petitions were received and considered, typically by referral to committees. The petition-response mechanism dealt procedurally with such controversial issues as contested election results, ${ }^{99}$ the National Bank, ${ }^{100}$ the expulsion of Cherokees from Georgia, ${ }^{101}$ land distribution, ${ }^{102}$ the abolition of dueling, ${ }^{103}$ government in the

94. 2 B. Schwartz, The Bill of Rights: A Documentary History 1026 (1971).

95. Id.; cf. Meiklejohn, The First Amendment Is an Absolute, 1961 Sup. Cr. Rev. 245, 255 ("The First Amendment does not protect a 'freedom to speak.' It protects the freedom of those activities of thought and communication by which we 'govern.' It is concerned, not with a private right, but with a public power, a governmental responsibility.").

96. 2 B. SchwaRTZ, supra note 94, at 1052-1105 (House debates).

97. Id. at 1105 (House vote negative, 10-41); id. at 1146 (Senate vote negative, 2-14).

98. Id. at 1093-94 (right to consult goes no further than petitioning, but representatives have duty to inquire into petitioners' suggested measures) (statement of R. Sherman); id. at 1094-95 (right to consult Congress is non-binding, but Congress has responsibility never to shut its ears to petitions) (statement of E. Gerry); id. at 1096 (right to bring non-binding instructions to Congress' attention is protected) (statement of J. Madison).

99. See, e.g., [1 Misc.] 20 american State Papers: Documents, Legislative and ExecuTIVE OF THE Congress of tHe United States, 1st Cong., 1st Sess. 5, 8, 9 (1978) (1st ed. 1834) (petitions and responses concerning disputed election of William Smith) [hereinafter AMERICAN PAPERS, cited by volume, document number, Congress, session, page, and original year]; [1 Misc.] 20 American Papers Nos. 41-42, 3d Cong., 1st Sess. 73-75 (1794) (petitioners brought before Committee of Elections concerning contested election of Albert Gallatin); [1 Misc.] 20 AMERICAN PAPERS No. 197, 9th Cong., 1st Sess. 436 (1806) (objection to election of Michael Lieb). See generally [2 Misc.] AMERICAN PAPERS at viii (indexed under "Reports of Committees of Election of the House of Representatives").

100. See, e.g., S. Journal, 22d Cong., 1st Sess. 65, 183 (1832) (Senator Dallas presented memorial of president, directors, and company of Bank of United States praying for renewal of charter).

101. See, e.g., H.R. Doc. No. 145, 20th Cong., 2d Sess. 1-3 (1829); H.R. Doc. No. 106, 21st Cong., 2d Sess. 1-5 (1831).

102. See generally [1-8 Public Lands] American Papers (great number of petitions referred to Committee on Private Land Claims).

103. See H. Journal, 25th Cong., 2d Sess. 647 (1838) (petitions prompting appointment of select committee to consider legislation abolishing dueling). 
territories, ${ }^{104}$ the Alien and Sedition Acts, ${ }^{100}$ and the slave trade. ${ }^{108}$ Generally, favorable legislation or an adverse report halted further petitioning.

Nonetheless, systemic strains appeared early in the nineteenth century. Since the daily business of Congress began with the reading by each state of its petitions, too many petitions could bring proceedings to a standstill. Groups like the American Anti-Slavery Society emerged with national constituencies able to mobilize such petitioning drives. The development of nationwide petitioning efforts, coupled with the Jacksonian sentiment that representatives owe "unrelaxing responsibility to the vigilance of public opinion,"107 made the petitioning process less a means by which legislators were informed of public opinion, and more an offensive device for propaganda. Failure to satisfy the petitioners' demands became a political garrote for accountability. ${ }^{108}$

Fundamentally, the right of petition lacked a secure foundation in the national legislature. Its roots in local assemblies vested with investigatory duties disappeared. The close geographical association between petitioners and colonial legislatures was lost. ${ }^{100}$ Developing judicial institutions re-

104. See, e.g., [1 Misc.] 20 American Papers No. 122, 6th Cong., 1st Sess. 203, 207 (1800) (petitioners seeking democratization of government of territority denied in committee); [1 MiSc.] 20 AMERICAN PAPERS 8th Cong., 2d Sess. 396-99, 417-18 (1804-05) (Louisiana planters petitioning to alter gubernatorial government; committee resolved "[t]hat provisions ought to be made by law for extending to the inhabitants of Louisiana the right of self-government").

105. See, e.g., 2 Abridgement of the Debates of Congress: 1789 to 1856, at 373, 384 (1857) (by early 1799, over 6,000 signatures against Acts sent to committee, which reported unfavorably; debate lengthened because "subject . . . had been brought before the House by the people, and ought, therefore, to receive a full discussion," id. at 384). [1 Misc.] 20 American PaPers 5th Cong., 3d Sess. 181-84 (1799); see also [1 Misc.] 20 American Papers No. 137, 6th Cong., 1st Sess. 215 (1800) (petitioners contesting Senate contempt resolution against Pennsylvania editor).

106. See, e.g., [1 Misc.] 20 American Papers No. 44, 3d Cong., 1st Sess. 76 (1794) (Quaker petition leading directly to enactment of Federal Slave Trade Act of 1794, which prohibited "the fitting out any ship or vessel in any port of the United States" for slave trade abroad), discussed in W. Wiecek, The SOURCES OF ANTISLAVery Constitutionalism IN AMERICA, 1760-1848, at 86 (1977).

107. An Introductory Statement of the Democratic Principle, from The Democractic Rev. (Oct. 1837), in Social Theories of Jacksonian Democracy 21, 23 (J. Blau ed. 1954). For other early nineteenth-century discussion of this matter, compare Virginia Assembly Report, 4 AM. L.J. 571,587 (n.s.) (J. Hall ed. 1813) (Virginia assembly resolution declaring "indubitable right of statelegislatures, to instruct their senators in Congress, on all points" and to deny appointment to individuals who refuse obedience) with Instructions to Representatives, 4 AM. JURIST 314 (Oct. 1830) (arguing that constituents' instructions be limited to advisory role lest directives govern Congressional proceedings).

108. In arguing that the ballot was sufficient protection for popular sovereignty, the Federalists anticipated precisely this danger of inserting in the Constitution a petition clause which "give[s] people an idea, that as individuals, or in town meetings, they have a power paramount to that of the Legislature." " N.Y. Daily Advertiser (Dec. 31, 1787) cited in 14 THE DOCUMENTARY HiSTORY OF THE RAtification of the Constitution 202 note 3.

109. The concept of a "natural limit of democracy" was shared by Federalists and Antifederalists alike. See G. Dietze, The Federalist 122 nn.60, 69 (1960). Antifederalists argued that citizens' self-government and immediate intercourse with their assembly, for instance through petitions, would be sacrificed if powers were vested in national representatives elected biannually and seated in a distant capital. See, e.g., The ANTIFEDERAlists 107-08, 133-34, 169, 184, 192, 212-13, 377-78 (C. 
moved private grievances from legislative attention. ${ }^{110}$ Congress, with its enumerated constitutional powers, did not rely on petitions to expand its jurisdictional reach. Finally, broadened franchise and the evolving party system diminished the need for legislators to inform themselves through popular, localized petitions.

\section{The Crisis over Abolitionist Petitions}

The slavery dispute brought these strains to a crisis. When abolitionists, invoking the First Amendment petition guarantee to secure a hearing and response, began to petition aggressively in the 1830's, Congress chose to retreat behind a legislative process that was inhospitable to activist petitioning. ${ }^{111}$

Congress first reacted to the abolitionists with motions to refuse their prayers. ${ }^{112}$ Later, members urged that petitions be tabled immediately or referred to select committees but that no action be taken. ${ }^{113}$ In 1840 , the House capitulated to Southern pressure for an absolute "gag" on antislavery papers by stating that no petitions or resolutions "praying the abolition of slavery . . . shall be received by this House, or entertained in any way whatever." 114 Controversy over both this and previous "gag rules" provoked heated discussion of the constitutional meaning of the right to petition. $^{115}$

Kenyon ed. 1985).

110. See, e.g., [1 Misc.] 20 American Papers Nos. 51, 65, 3d Cong., 2d Sess. 81, 123-24, 123 (1794-95) (New Hampshire legislature's petition to Congress against federal court action denied as "wholly judicial" question); [1 Misc.] 20 American Papers No. 102, 5th Cong., 2d Sess. 163-66 (1798) (Quaker petitioners told to withdraw memorial concerning manumitted slaves because state court proper and adequate forum); [1 Misc.] 20 American Papers No. 160, 7th Cong., 2d Sess. 340 (1803) (lower federal judges' petitions protesting law depriving them of offices said to involve constitutional question better handled by courts).

111. Standard historical works on abolitionism and American constitutional history contain only incomplete examinations of the 1830's petition crisis. See, e.g., G. BARnes, The Antislavery IMPULSE, 1830-1844, at 88-150 (1933) (detail on theological and organizational underpinnings of antislavery petition campaigns); R. Nye, FetTered Freedom: Civil Liberties and the Slavery Controversy, 1830-1860, at 41-85 (1963) (mail interruption); 2 H. Von Holst, The ConstTtutional and Political History of the United States 235-92, 467-86 (1888) (general discussion).

112. See, e.g., [1 Misc.] 20 American Papers No. 13, 1st Cong., 2d Sess. 12 (1790).

113. See, e.g., H. Journal, 25th Cong., 2d Sess. 127 (1837); H.R. Doc. No. 215, 20th Cong., 1st Sess. (1828); see also W. WIECEK, supra note 106, at 184.

114. Cong. Globe, 26th Cong., 1st Sess. 150 (1840).

115. See, e.g., H.R. REP. No. 3, 28th Cong., 1st Sess. 14-20 (1844), reported in REPS. or Comms. No. 3, 28th Cong., 1st Sess. 14-20 (1844); $c f$. Brest, The Conscientious Legislator's Guide to Constitutional Interpretation, 27 STAN. L. REv. 585 (discussing legislators' duty to interpret and honor Constitution). 


\section{A. The Southern Position}

Championing the slave-holding states in the Senate, John Galhoun viewed the requirement of consideration as a grave menace and a fundamental violation of each house's constitutional right to determine the rules of its proceedings. ${ }^{116}$ Southern representatives denied that the right of petition extended to control of assembly action, arguing that assemblies would be little more than "passive receptacles" were petitioners' rights held superior to legislative necessities. ${ }^{117}$ Thus, Galhoun supported a sharp demarcation between citizenry and legislators. The right of the former to assemble and communicate opinions to the government ceased upon presentation of a petition; ${ }^{118}$ thereafter, the legislative domain was absolute and the assembly had full discretion to interpret and devise its own rules. ${ }^{119}$

Southerners also decried petitioners' use of the government to interrogate the South on its laws, policies and institutions. ${ }^{120}$ Southern representatives refused to allow petitioners to compel a moral debate on the subject of slavery. ${ }^{121}$ "Such a contest is beyond mortal endurance," Galhoun argued, "[w]e must in the end be humbled, degraded, broken down, and

116. 2 The Works of John C. Calhoun, 487, 480 (J. Cralle ed. 1853) (referring to U.S. Constitution, art. 1, $\S 5, \mathrm{cl}$. 2) (hereinafter Works of CAlHoun, cited by volume]; see also Letter from Honorable H. Otis to J. Whipple, Esq., Rhode Island State Legislature (Jan. 23, 1839), and Reply (March 1, 1839), reprinted in R.I. REPS. 5-7 (petitioning is "a right to individual action, and not a right to control legislative action"); id. at 22 (fear that "every vaguery" will command legislative time) (available in Library of Congress: E449.R46) [hereinafter R.I. REPS.].

117. 2 Works of Calmoun 481; see also The Right of Petition, Remarks in the Senate on Various Petitions and Other Matters Connected with the Subject of Slavery 14 (Feb. 12, 1850) (Congressional processes "appropriated by mischievous incendiaries") (available on microfilm in Library of Congress); Speech of Mr. Rayner, of North Carolina, on the Question of the Reception of Abolition Petitions. Delivered in the House of Representatives 5 (June 15, 1841) ("the inherent and necessary right of every legislative body to protect itself . . . in the exercise of its legal functions") (available in Library of Congress) [hereinafter Address by Congressman Rayner].

118. See 2 Works of Calhoun 467, 469. Though consistent with recent case law, see supra note 2 , this bifurcation runs counter to colonial practice, where petitioning in fact did turn citizens into lawmakers.

119. R.I. REPS., supra note 116, at 5 (petitions part of proceedings, "to be regulated solely and exclusively by the House").

120. See, e.g., S. Journal, 25th Cong., 2d Sess. 83 (1837); Reps. of Comms. No. 404, 28th Cong., 1st Sess. 35 (1844) ("there is no right to employ the government as an instrument of dangerous agitation"); Speech by William Cost Johnson, of Maryland, on the Subject of the Rejection of Petitions for the Abolition of Slavery; with Supplemental Remarks. Delivered in the House of Representatives 11-13 (Jan. 25, 27, 28, 1840) (available in Library of Congress) [hereinafter Address by Congressman Johnson]. Petitioning in colonial America performed precisely this inquisitorial function. Colonists prayed to assemblies to investigate and redress their grievances, and wrongdoers had no privilege to be "left alone."

121. See Commonwealth v. Barrett, 36 Va. (9 Leigh) 665 (1839). Lysander Barrett and ten others were charged with violation of a Virginia act "to suppress the circulation of incendiary publications." Id. Barrett's paper was an anti-slavery petition to Congress and is reprinted in 1 Judicial Cases Concerning American Slavery and the Negro 195-96 (H. Catterall rev. ed. 1968); see also 2 WORks of CALHOUN 490 ("We cannot remain here in an endless struggle in defence of our character, our property, and institutions."). 
worn out."122 Charging that abolitionists' petitions were designed for agitation and not for genuine redress of grievances, ${ }^{123}$ Southern members stressed the preservation of states' rights. Abolitionists could have no voice in the design of Southern institutions. "The discussion, on our part," exclaimed Congressman Rayner of North Carolina, "is of a defensive character-we want no discussion-we call for no action-but we simply ask to be let alone." 124

Southerners accused anti-slavery petitioners of guising libel and sedition as free discussion. ${ }^{125}$ They were adamant that petitioners could seek only redress of grievances that were felt and manifest; no petitioner was entitled to initiate legislation which would leave her or him unaffected. ${ }^{228}$

Petitioners' anti-slavery agitation was decried as unlawful. First, the original compromises necessary to draft the Constitution, such as basing representation on the slave population, were said to estop challenges to slavery. ${ }^{127}$ Second, abolitionists' petitions were blamed for inflaming sectarian controversies, arousing prejudices, and fostering disunion. This libel and illegality suspended the normal privilege of consideration. ${ }^{128}$ In the words of one Congressman: "I maintain that slavery having preexisted--having been recognized, adopted, and guarantied by the constitution-no afterthought of fanaticism or pretended humanity can, for specious purposes, seize upon the property of any citizen . . . ."128

Southern demands for nonintervention coalesced in a jurisdictional ar-

122. 2 Works of Calhoun 483. The South's slavery posture was one of silence. Calhoun was adamant that "[t]he most unquestionable right [Southern slavery] may be rendered doubtful, if once admitted to be a subject of controversy . . . J" Calhoun, Speeches of John C. Calhoun 223 (1843).

123. See, e.g., C. Colton, Abolition a Sedrion: by a Northern Man, Calvin Colton 16-17, 53-54 (1839) (American Anti-Slavery Society agitating against Constitution); R.I. REPS., supra note 116, at 8 (petitions "an attempt to add political heat to abolition fury").

124. Address by Congressman Rayner, supra note 117, at 13 .

125. See, e.g., S. Doc. No. 249, 24th Cong., 1st Sess. 2 (1836) ("under the miserably perverted name of free discussion, these incendiaries will be permitted to scatter their firebrands throughout the country").

126. See, e.g., H. Journal, 25th Cong., 3d Sess. 168 (1838) (slavery not a grievance to Southerners).

127. See, e.g., H.R. Rep. No. 691, 24th Cong., 1st Sess. 10 (1836); H. Journal, 24th Cong., 1st Sess. 148 (1836); S. Misc. Doc. No. 110, 31st Cong., 1st Sess. 2 (1850) (slavery, protected by Constitution, may be modified by states only).

128. See, e.g., S. Doc. No. 75, 24th Cong., 2d Sess. 2-3 (1837) (protesting "monstrous encroachment" of abolitionists, whose libelous petitions violated the constitutional aim of "domestic tranquility"); H. Journal, 25th Cong., 3d Sess. 277-78 (1839); S. Misc. Doc. No. 48, 30th Cong., 2d Sess. 2 (1849) (petitions for law abolishing slavery in District of Columbia " a direct attack upon the institutions of the southern States").

129. Address by Congressman Johnson, supra note 120 , at 23; see also H. Journal, 26 th Cong., 1st Sess. 144 (1839). "Gag" proponents alleged a blatant contradiction between emanicipation petitions and the constitutional guarantee of property. See, e.g., 3 WORKS OF CALHOUN 443 ("Is it not a direct infraction, then, of the Constitution, to present petitions here, in the common council of the Union, and to us, the agents appointed to carry its provisions into effect, and to guard the rights it secures, the professed aim of which is to destroy the property guaranteed by the instrument?"). 
gument against petitioners' right to hearing. Denying Congress' constitutional authority to abolish slavery, Galhoun concluded that individuals seeking abolition had no just right to petition the legislature. His states' rights and nullification doctrines ${ }^{130}$ described a federal government of strictly limited powers whose constitutive charter recognized slavery and conceded its control to states. Reasoning from the alleged constitutional immunity of slavery, members opposed recognition of abolitionists' petitions. ${ }^{131}$ The contest centered on reception; once petitions were admitted and jurisdiction conceded, further protest could attack only the substance of petitions and not the extension of federal authority over slavery. ${ }^{\mathbf{1 3 2}}$

But improper jurisdiction itself was unclear. Abolitionists prudently narrowed their target to slavery in the nation's capital. ${ }^{133}$ Whereas Southerners saw the strategy bridging to a campaign against the South, in fact the restraint undermined the pro-slavery opposition to Congressional overreaching. Though most representatives acknowledged the states' absolute authority to legislate with respect to slavery, lawmaking for the District of Columbia was altogether different. ${ }^{134}$ Express constitutional language vested Congress with lawmaking power over the capital. ${ }^{135}$ Proslavery advocates retorted that the duties of Congress towards the capital must parallel those of a local legislature, attentive only to its inhabitants. ${ }^{138}$ Moreover, Virginia and Maryland claimed that their cession of lands to the District included an implicit guarantee that property (slaves) would remain inviolate. ${ }^{137}$

130. See $2 \mathrm{H}$. Von Holst, supra note 111, at 272.

131. See, e.g., S. Doc. No. 81, 24th Cong., 1st Sess. 2-3 (1836); Address by Congressman Johnson, supra note 120 , at $5,29,34$ ("We cannot of right be petitioned to do that which we have no constitutional power to do, much less that which we have sworn not to do."). Northern antagonism to slavery, "gag" proponents argued, was an attempt through petitions to costume their true design to aggrandize power in the national government against Southern interests. See 2 A. STEPHENS, CoNSTItutional. View of the Late War Between the States: Its Causes, Character, Conduct, AND RESULTS 28-29 (reprint 1970).

132. Tremain, Slavery in the District of Columbia, 1-2 NeB. U. Seminary PaPers 87-88 (1981-82) (quoting Congressman Wise's remarks that if a "gag" still allows reception of anti-slavery petitions "the whole ground is gone and the abolitionists have triumphed, because . . . if you have the power to report at all, you may report favorably as well as unfavorably").

Again, this Southern position contradicted the original meaning of the petition right, for in colonial America citizens petitioned assemblies for relief precisely when existing law offered no answer. The assemblies, in turn, encouraged petitions which might extend their jurisdiction.

133. See, e.g., H. Journal, 24th Cong., 1st Sess. 193-97, 539 (1836).

134. See generally Tremain, supra note 132 (general discussion of slavery in the capital); see also Speech of Mr. Severance, of Maine, on the Right of Petition. Delivered in the House of Representatives 3 (Feb. 16, 1844) (jurisdiction of Congress over capital warrants anti-slavery petitions) (available in Library of Congress) [hereinafter Address by Congressman Severance].

135. U.S. CoNST. art. I, $\$ 8$, cl. 17.

136. See, e.g., H.R. REP. No. 60, 20th Cong., 2d Sess. 5 (1829) (committee report that citizens of states not qualified to petition on local matters in capital); S. Doc. No. 75, 24th Cong., 2d Sess. 2 (1837) (petitioners obtrude in domestic affairs of District, where Congress must act as "local legislature").

137. H.R. Doc. No. 152, 27th Cong., 2d Sess. 1 (1842); see also Tremain, supra note 132, at 


\section{B. The Northern Anti-Slavery Position}

The leading spokesman in Congress for the anti-slavery petitioners was John Quincy Adams. Though sympathetic to the anti-slavery cause, Adams regarded abolitionist petitioning as politically ill-advised. ${ }^{138}$ Nonetheless, he thought himself obliged to present the papers. ${ }^{139}$ Congress had to protect the citizenry's two constitutional means of approaching the government: periodic election and continual instruction through petitioning. ${ }^{140}$ Defending the right of every person to petition Congress, whatever the motive, Adams declared that each petition was entitled to a hearing on its merits. ${ }^{141}$

Participation by ballot and petition not only assured popular control of government, but also attached to each citizen responsibility for the nation's laws, or lack thereof. ${ }^{142}$ Slavery, above all slavery in the nation's capital, was an affront to the national conscience. Petitions, because they entailed personal commitment and resolve, ${ }^{143}$ were encouraged as means by which citizens could disassociate themselves from the evils of slavery. William Channing, a leading abolitionist, proclaimed: "The District of Columbia fastens on the whole nation the guilt of slaveholding . . . . And I hold it the duty of every man in the free States . . by solemn remonstrance to Congress, to purge his conscience of the nation's crime."144

Abolitionists also argued that slavery caused direct grievance because it intruded on national affairs, threatened domestic tranquility, and obstructed interstate relations. ${ }^{145}$ Such injuries, they claimed, warranted the

69; Address by Congressman Johnson, supra note 120, at 53 ("Two hundred and fifty members lof Congress] were never intended to be set over the people of this District as absolute masters, tyrants, disposers of the rights of property....").

138. See S. BEMIS, John Quincy ADAMs AND THE UnION 380 (1956) ("I wish distinctly to aver ... that though I have earnestly advocated the right of persons to petition for the abolition of slavery in the District of Columbia, I myself am not prepared to grant their prayer.").

139. Id.

140. See, e.g., 1 The ANti-Slavery Examiner 3 (Aug. 1836) (petitioning essential to informed voting and legislation).

141. See J. Q. Adams, List of Petitions, National Intelligencer, Apr. 23, 1839, at 2, col. 4; Speech of Mr. Cushing, of Massachusetts, on the Right of Petition, as Connected with Petitions for the Abolition of Slavery and the Slave Trade in the District of Columbia in the House of Representatives 11 (Jan. 25, 1836) (every citizen's right to be heard on floor of House essential to democracy) (available in Library of Congress) (hereinafter Address by Congressman Cushing].

142. See, e.g., The National Era, Jan. 18, 1849, at 10, col. 2 (concerning petitioning against slavery, "those who elect the law-makers are responsible for the laws made, or for the neglect to pass laws which ought to be enacted").

143. See, e.g., W. WIECEK, supra note 106, at 184. But see H. Thoreau, Resistance to Civil Government, reprinted in 1 AMERICAN IssuEs 494, 496 (W. Thorp, M. Curti \& C. Baker eds. 1944) (persons opposed to slavery do little, "[t]hey hesitate, and they regret, and sometimes they petition; but they do nothing in earnest and with effect").

144. W. Channing, Remarks on the Slavery Question, in a Letter to Jonathan Phillips, EsQ. 15, 17 (1839).

145. For example, interstate relations were impeded by Southern mail regulations, which were designed to intercept abolitionist mailings. W. SAvage, The Controvery over the Distribution 
petitioning by free states for legislative change. ${ }^{146}$ And even if Northern interests were less evident, the First Amendment protection of petitioning was said to be absolute. No personal, social or moral conditions could be imposed on the exercise of the right. ${ }^{147}$

Abolitionists warned that a "gag" against anti-slavery petitions might, with equal facility, silence other matters of public concern. ${ }^{148}$ They feared that one branch of Congress could by itself limit the scope of constitutional protection by summarily denying citizens the right of prayer. ${ }^{140}$ Barring consideration of a class of petitions was criticized as an arbitrary act, akin to a judicial decision pronounced in advance of the facts. ${ }^{150}$ Adams and others declared that minority political expression would be silenced if petitioning were confined only to those subjects approved by a majority in Congress. ${ }^{151}$ At bottom, the "gag" opponents insisted that the right to petition implied duties to hear, consider, debate, and decide. ${ }^{\mathbf{1 5 2}}$ Even if want of authority required the ultimate denial of a petition, the preliminary rights of communication and consideration ought not to be infringed. ${ }^{103}$ This logic took vivid illustration in the controversy over Adams's introduction of a petition from Haverhill, Massachusetts, requesting

OF ABolition LITERATURe, 1830-1860 (1938).

146. Address by Congressman Severance, supra note 134 , at 14 .

147. See, e.g., Address by William Jay to the Friends of Constitutional Liberty on the Violation by the United States House of Representatives of the Right of Petition (Feb. 13, 1840), in W. JAY, Miscellaneous Writings on Slavery 397, 401-02 (1853) (charges that people denied access to representatives on any matter are "gagged") (hereinafter Address by William Jay]; H. JouRNAL, 26th Cong., 1st Sess. 788 (1840) (Massachusetts resolution affirming Congress' duty to give all petitioners "respectful and deliberate consideration," "however mistaken in their views, or insignificant in number").

148. See Address by William Jay, supra note 147 , at 402 .

149. See, e.g., The Right of Petition, Remarks in Senate, supra note 117, at 7, 9; Letter from John Quincy Adams to the Twelfth Congressional District of Massachusetts (Mar. 3, 1837), in J. Q. ADAMS, LeTTERS FROM JOHN QuinCY ADAMS TO his CONSTTTUENTS OF THE TWELFTH CONGRESsional. District in Massachusetts. To Which Is Added His Speech in Congress, DelivERED FEB. 9, 1837, at 5, 40 (1837) ("gag" law violates principle that House is not competent to define Constitutional rights) (available in Library of Congress).

150. Adams charged that the right to petition had been impeached when a petition for Mexican arbitration concerning Texas, which had been sent to committee for report, was later discovered to have been put with all anti-Texas petitions and ignored. See S. BEMIS, supra note 138, at 363-369.

151. See, e.g., The National Era, Jan. 18, 1849, at 10, col. 1 ("gross evasion" of democratic system where petition reception depended on consent of majority); Address of John Quincy Adams on the Resolutions To Censure Him for Inquiring of the Speaker, Whether a Paper Purporting To Be from Slaves, Came Within the Order of the House, Which Laid on the Table All Petitions Relating to Slavery, in J.Q. ADAMS, supra note 149, at 45, 52 ("gag" rule would "reduce the right of petition to nothing more than the right of the predominant party, for the time being, to petition").

152. See, e.g., S. Journal, 25th Cong., 2d Sess. 136-37 (1838) (Senate motions interpreting the right of petition "to include the duty ... to receive and determine upon the prayer of the petitioners").

153. See, e.g., The National Era, Jan. 18, 1849, at 10, col. 2 ("The want of power is a good reason for not granting the prayer of a petition, but no reason for refusing to receive the petition itself."); J. Q. Adams, List of Petitions, National Intelligencer, Apr. 23, 1839, at 2, col. 4 (distinguishing between implied rights of reception and hearing and Congress' discretion to reject prayer on merits). 
dissolution of the Union. Members moved to censure Adams on the grounds that the right of petition could not extend to destruction of the sovereign power petitioned. Adams, while admitting that Congress could not take such action, denied that the unavailability of the requested remedy should preclude the processes of petition and hearing. Recalling the events of 1776 and " 'the right of the people to alter, to change, to destroy, the Government if it becomes oppressive to them,' " Adams concluded, "I rest that petition on the Declaration of Independence." "164

Northerners warned that no government should assume that it could not reason with its citizens. Hence, for Haverhill townspeople and abolitionists alike, Adams' response was: " 'I say that if the petition is referred and answered, it will satisfy the petitioners.' "15s Together with a faith in democracy came disdain for the belief that anti-slavery opinion could be silenced. One state communication to Congress described the "gag" as an "unphilosophical and absurd mode to stop the progress of reform, or the spread of fanaticism."168

Adams, like Calhoun, sought to differentiate petition from assembly powers. Yet, whereas the representatives of the slave-holding states found balance in a presentation-reception distinction, Adams gave more authority to citizens. Citizens had the liberty, even the responsibility, to petition on any matter, irrespectively of the legislature's power of redress. Since both offer and consideration were indispensable to effective petitioning, the correct line lay between the guarantee of those two rights and the assembly discretion to deny or disapprove a particular petitioner's request. The right to petition carried a mandate of hearing, but not of approval.

Finally, abolitionists protested that the "gag rules" not only subverted popular self-government, but also nullified members' freedom of speech and proposal. ${ }^{157}$ A rule proscribing introduction of certain matters as offenses against the House, Southern States, or the Union, choked debate. Lawmaking subject to majority caprice, with the extent of encroachment varying with each "gag" resolution, was said to make a mockery of the speech and debate privilege of representatives. Accordingly, when the House clamored to censure Adams for acting on a petition from slaves, the New Englander's reply was acerbic: "The whole doctrine of contempts

154. S. BEMIs, supra note 139 , at 427-31. Congressman Cushing also came to the defense of the Haverhill petitioners and stated that any person has a right to be heard, "be he fanatic or be he philosopher." Address by Congressman Cushing, supra note 142, at 3 .

155. S. Bemis, supra note 138 , at 431.

156. H. Journal, 26th Cong., 1st Sess. 788 (1840).

157. See, e.g., H. Journal, 25th Cong., 2d Sess. 347 (1838); Letter from John Quincy Adams to the Twelfth Congressional District of Massachusetts (Mar. 3, 1837), in J.Q. AdAMs, supra note 149, at 29; RePs. of Comms. No. 404, 28th Cong., 1st Sess. 17 (1844) ("['Gag'] is a perpetual denial to the House of the power to deliberate on the means of ameliorating the condition of the people ...."). 
... is a law of tyranny, in which the House is at once acuser, party, judge, and executioner."188

\section{Concluston}

The controversy over the right to petition, which involved diametrically opposed congressional interpretations of the First Amendment, highlights the elasticity of constitutional language. The essence of the dispute centered on whether the petition clause supplied merely a "presentative" right-the individual's right to voice grievances to Congress-or whether it went further to dictate a procedure for disposal, with an unqualified requirement that Gongress receive and consider petitions. Despite the clear colonial practice that linked petitioning to a corollary duty of legislative response, the Southern "gag" proponents successfully challenged this link and subsumed the right within free expression. The abrupt defeat of a right so indispensable to the colonial legislative process has two explanations: first, the frailty of the right of petition, a right uprooted from the social and political context in which its use had flourished, and second, more broadly, the assailability of any principle, however fundamental, when confronted by interests as entrenched as slavery. Transport a right from an altogether different political culture into a period of intense political antagonisms, and constitutional language and purpose are readily subverted. The right to petition was ill-fitted to lawmaking in the national legislature; but, perhaps more decisively, it had the misfortune to become inextricably entangled in the slavery crisis.

To explore the consequences of reinstituting the colonial process of lawmaking and representation through popular petitions would be to reargue the Federalist-Antifederalist debate, in a twentieth century context. That is too ambitious. ${ }^{169}$ Holding to historical argument nonetheless suggests an

158. Letter from John Quincy Adams to the Twelfth Congressional District of Massachusetts (Mar. 3, 1837), in J.Q. ADAMS, supra note 149, at 21.

159. One might, however, recognize petitioning as a constitutionally mandated feature of the lawmaking process. Like such procedural requirements as majority, bicameral enactment, and independent executive assent, the petition clause may add a dimension to legislative accountability by making lawmaking more adjudicative, with deliberations open to petitioners' voices. $C f$. Linde, Due Process of Lawmaking, 55 NEB. L. REv. 197, 235-55 (1976) (due process application to process of lawmaking would incorporate Bill of Rights procedures). This authority of persons, as before courts, see Fiss, The Supreme Court, 1978 Term-Foreword: The Forms of Justice, 93 HARv. L. REv. 1, 13 (1979) (judges do not control agendas; rather, they must listen and respond to grievants), to command a public hearing before lawmakers, has constitutional analogy in article 1, section 5's empowerment of a minority of either House to force a public, recorded vote on "any question." U.S. CoNST. art. I, § 5, cl. 3. Interview with Akhil Amar, Assisitant Professor of Law, Yale Law School (Aug. 10, 1986). Specific lessons could be taken from colonial America, where it has been shown that assemblies' treatment of petitions involved processes of fair notice and hearing. The modern state does attach a right of petition hearing to some executive and administrative bodies' proceedings. See, e.g., 5 U.S.C. \& 553(c) (1982) (agency rulemaking). This view identifies petitioning with the legislative process, as an indispensable complement to suffrage: by the latter citizens elect their government, and by the former they 
important lesson. The historian may chide legal scholars and judges alike who, while protesting fidelity to the Framers' intent, have in fact acquiesced in the evisceration of the original meaning of the right to petition, a right which had compelled legislatures to accord citizens' petitions fair hearing and consideration.

Legal scholarship must be honest. If courts continue to confine the First Amendment petition guarantee to presentation, or free expression as in McDonald ${ }^{160}$ and Minnesota State Board, ${ }^{161}$ they should be candid about the inconsistency with the Framers' intent. To be sure, rights and methods of lawmaking may be bound to historical eras. The original character of the right to petition may impose an untenable restraint on the autonomy and agenda setting power of the federal legislature. But until this conclusion is made, court opinions will appear to rest not on the Framers' intent, but on deference to the resolve of antebellum Congresses to defeat a right which threatened the institution of slavery.

continually inform it of their will. A reassertion in the legislative sphere of this procedural requirement of consideration might check legislative irresponsibility, especially the ills of ignorance, arbitrariness, and majoritarian insensitivity.

160. McDonald v. U.S., 105 S. Ct. 2787 (1985); see supra note 2.

161. Minnesota State Bd. for Community Colleges v. Knight, 465 U.S. 217, 283 ("The Constitution does not grant to members of the public generally a right to be heard by public bodies making decisions of policy."). 